\title{
Geographic distribution of the genus Siphlophis Fitzinger, 1843 (Colubridae, Dipsadinae, Serpentes) in Colombia
}

\author{
Andrés Aponte-Gutiérrez, ${ }^{1,2}$ Fernando Vargas-Salinas ${ }^{3}$ \\ 1 Fundación Biodiversa Colombia, Carrera 22 número 41-80 apartamento 401, 11001, Bogotá D.C., Colombia. 2 Fundación Reserva Natural La \\ Palmita, Cra 4 No. 58-59, Bogotá D.C., Colombia. 3 Programa de Biología, Facultad de Ciencias Básicas y Tecnologías, Universidad del Quindío, \\ Carrera 15, Calle 12 Norte. 05059, Armenia, Colombia. \\ Corresponding author: Andrés Aponte-Gutiérrez, felipeherpetologia@gmail.com
}

\begin{abstract}
Little is known in Colombia about the distribution, ecology, and natural history of the snakes included in the genus Siphlophis. Here, based on analysis of specimens deposited in zoological museums and data from literature, we update the information about the geographic distribution of Siphlophis cervinus and Siphlophis compressus in Colombia.
\end{abstract}

Key words

Snakes; northern South America; biodiversity lowlands.

Academic editor: Rafael de Fraga | Received 31 March 2017 | Accepted 6 November 2017 | Published 2 February 2018

Citation: Aponte-Gutiérrez A, Vargas-Salinas F (2018) Geographic distribution of the genus Siphlophis Fitzinger, 1843 (Colubridae,

Dipsadinae, Serpentes) in Colombia. Check List 14 (1): 195-201. https://doi.org/10.15560/14.1.195

\section{Introduction}

The genus Siphlophis Fitzinger, 1843 is composed of 7 species of snakes distributed from Costa Rica in Central America to Bolivia and Brazil in South America (Barrio et al. 1998, Uetz et al. 2016). Siphlophis is considered a monophyletic group in the family Colubridae (Dipsadinae), nested in the tribe Pseudoboidini with the genus Clelia Fitzinger, 1826, Pseudoboa Schneider 1801, and Oxyrhopus Wagler, 1830 (Pyron et al. 2011, Uetz et al. 2016). Two species of the genus Siphlophis are known in Colombia: Siphlophis cervinus Laurenti 1768 and Siphlophis compressus Daudin 1803 (Sánchez-C et al. 1994). Siphlophis cervinus has been recorded in Peru (Duellman and Salas 1991), Brazil (Frota et al. 2005), Ecuador (Almendariz 1991), Venezuela (Barrio et al. 1998), French Guyana (Gasc and Rodrigues 1980, Chippaux 1986), and Panama (Pérez-Santos 1999); S. compressus occurs in Peru (Espinoza and Icochea 1995), Brazil (Barreto et al. 2011), Venezuela (Barrio-Amorós et al. 2010), French
Guyana (Chippaux 1986, Claessen 2005), and Costa Rica (Solorzano 2006).

Pérez-Santos and Moreno (1988) suggested that $S$. cervinus is present in Colombia in the departments of Chocó and Guaviare, while $S$. compressus is present in Amazonas, Boyacá, Cauca, Chocó, Meta, Putumayo, and Valle del Cauca. However, that contribution was strongly criticized because the authors did not associate occurrence data with museum specimens, and the distribution and taxonomic descriptions of some species have several mistakes (Cadle, 1992). Sánchez et al. (1994) suggested that S. cervinus is present in the Alto Apaporis and Chocó, while $S$. compressus is present in Amazonas, Orinoco and Pacific coast, but they did not specify departments or localities. Since accurate information about distribution of species is important for understanding their evolutionary history and optimizing management plans when necessary, this paper seeks to update the distribution map of the 2 Siphlophis species in Colombia. 
Table 1. Locality records for snakes of the genus Siphlophis (Colubridae) in Colombia. ANDES-R: Reptile collection, Universidad de los Andes; ICN: Instituto de Ciencias Naturales, Universidad Nacional de Colombia, Bogotá DC; IAVH-R: Reptile collection, Instituto de Investigaciones Biológicas Alexander Von Humboldt, Villa de Leyva, Boyacá, Colombia; MHUAN-R: Museo Herpetológico Universidad de Antioquia, Colombia; MLS: Museo la Salle, Universidad de la Salle; UIS-R: Reptile Collection, Universidad Industrial de Santander, Colombia; UTCH:COLZOOCHH: Colección Científica de Referencia Zoológica del Chocó - Herpetología, Universidad Tecnológica del Chocó. A long dash (一) means that there are no available geographic coordinates.

\begin{tabular}{|c|c|c|c|c|}
\hline \multirow[b]{2}{*}{ Siphlophis sp. } & \multirow[b]{2}{*}{ Museum code } & \multirow[b]{2}{*}{ Locality } & \multicolumn{2}{|c|}{ Geographic coordinates } \\
\hline & & & Latitude & Longitude \\
\hline S. cervinus & ANDES-R 0306 & Antioquia, Yondó & $06^{\circ} 42^{\prime} 54^{\prime \prime} \mathrm{N}$ & $074^{\circ} 20^{\prime} 10^{\prime \prime} \mathrm{W}$ \\
\hline S. cervinus & IAVH-R 3671 & Amazonas, Leticia & $04^{\circ} 07^{\prime} 16^{\prime \prime} \mathrm{S}$ & $069^{\circ} 57^{\prime} 18^{\prime \prime} \mathrm{W}$ \\
\hline S. cervinus & MHUA-R 12369 & Antioquia, Yondó & $06^{\circ} 43^{\prime} 40^{\prime \prime} \mathrm{N}$ & $074^{\circ} 18^{\prime} 52^{\prime \prime} \mathrm{W}$ \\
\hline S. cervinus & IAVH-R 1967 & Chocó, Río Sucio & $07^{\circ} 35^{\prime} 53^{\prime \prime} \mathrm{N}$ & $077^{\circ} 03^{\prime} 48^{\prime \prime} \mathrm{W}$ \\
\hline S. cervinus & IAVH-R 3858 & Amazonas, Parque Amacayacu & $03^{\circ} 39^{\prime} 07^{\prime \prime} \mathrm{S}$ & $070^{\circ} 31^{\prime} 26^{\prime \prime} \mathrm{W}$ \\
\hline S. cervinus & ICN 096 & Vaupés, Alto Apaporis & - & - \\
\hline S. cervinus & ICN 8153 & Vaupés, Caparú & $01^{\circ} 07^{\prime} 21^{\prime \prime} \mathrm{S}$ & $069^{\circ} 31^{\prime} 24^{\prime \prime} \mathrm{W}$ \\
\hline S. cervinus & ICN 11156 & Boyacá, Serranía de las Quinchas & $05^{\circ} 49^{\prime} 29^{\prime \prime} \mathrm{N}$ & $074^{\circ} 19^{\prime} 30^{\prime \prime} \mathrm{W}$ \\
\hline S. cervinus & MHUA-R 14934 & Antioquia, Necoclí & $08^{\circ} 29^{\prime} 23^{\prime \prime} \mathrm{N}$ & $076^{\circ} 49^{\prime} 05^{\prime \prime} \mathrm{W}$ \\
\hline S. cervinus & MLS-719 & Caquetá, Florencia & $01^{\circ} 45^{\prime} 00^{\prime \prime} \mathrm{N}$ & $075^{\circ} 34^{\prime} 59^{\prime \prime} \mathrm{W}$ \\
\hline S. cervinus & UTCH:COLZOOCH-H:0338 & Chocó, Rio Atrato & $05^{\circ} 35^{\prime} 00^{\prime \prime} \mathrm{N}$ & $076^{\circ} 38^{\prime} 56^{\prime \prime} \mathrm{W}$ \\
\hline S. cervinus & UTCH:COLZOOCH-H: 0595 & Chocó, Medio Atrato & $06^{\circ} 00^{\prime} 08^{\prime \prime} \mathrm{N}$ & $076^{\circ} 46^{\prime} 42^{\prime \prime} \mathrm{W}$ \\
\hline S. cervinus & UIS-R-001804 & Santander, Girón & $07^{\circ} 03^{\prime} 44^{\prime \prime} \mathrm{N}$ & $073^{\circ} 18^{\prime} 34^{\prime \prime} \mathrm{W}$ \\
\hline S. compressus & ICN 11342 & Amazonas, Km 11 vía Tarapacá & $04^{\circ} 07^{\prime} 16^{\prime \prime} \mathrm{S}$ & $069^{\circ} 57^{\prime} 18^{\prime \prime} \mathrm{W}$ \\
\hline S. compressus & ICN 9375 & Amazonas, Santa Sofía & $04^{\circ} 00^{\prime} 33^{\prime \prime} \mathrm{S}$ & $070^{\circ} 08^{\prime} 01^{\prime \prime} \mathrm{W}$ \\
\hline S. compressus & IAVH-R 0143 & Antioquia, Saragoza & - & - \\
\hline S. compressus & IAVH-R 1030 & Amazonas, Parque Amacayacu & - & - \\
\hline S. compressus & IAVH-R 2908 & Vaupés, Lago Taraira & $01^{\circ} 07^{\prime} 21^{\prime \prime} \mathrm{S}$ & $069^{\circ} 31^{\prime} 24^{\prime \prime} \mathrm{W}$ \\
\hline S. compressus & IAVH-R 3395 & Arauca, Arauca & - & - \\
\hline S. compressus & IAVH-R 3579 & Risaralda, Santa Cecilia & - & - \\
\hline S. compressus & IAVH-R 4381 & Vaupés, Lago Taraira & $01^{\circ} 07^{\prime} 21^{\prime \prime} \mathrm{S}$ & $069^{\circ} 31^{\prime} 24^{\prime \prime} \mathrm{W}$ \\
\hline S. compressus & IAVH-R 5144 & Vichada, Cumarimbo & $05^{\circ} 21^{\prime} 20^{\prime \prime} \mathrm{N}$ & $068^{\circ} 01^{\prime} 28^{\prime \prime} \mathrm{W}$ \\
\hline S. compressus & IAVH-R 5429 & Valle del Cauca, Rio Tatauro & - & - \\
\hline S. compressus & IAVH-R 5767 & Boyacá, Cubara & - & - \\
\hline S. compressus & ICN 0105 & Santander, Landázuri & $06^{\circ} 19^{\prime} 12^{\prime \prime} \mathrm{N}$ & $073^{\circ} 51^{\prime} 29^{\prime \prime} \mathrm{W}$ \\
\hline S. compressus & ICN 1524 & Valle del Cauca, Rio Saija & $02^{\circ} 49^{\prime} 24^{\prime \prime} \mathrm{N}$ & $077^{\circ} 32^{\prime} 54^{\prime \prime} \mathrm{W}$ \\
\hline S. compressus & ICN 7267 & Meta, Cubarral & - & - \\
\hline S. compressus & ICN 7911 & Boyacá, Puerto Boyacá & - & - \\
\hline S. compressus & ICN 7999 & Guainía, Puerto Inirida & $03^{\circ} 37^{\prime} 42^{\prime \prime} \mathrm{N}$ & $067^{\circ} 53^{\prime} 02^{\prime \prime} \mathrm{W}$ \\
\hline S. compressus & ICN 8172 & Vaupés, Caparú & $01^{\circ} 07^{\prime} 21^{\prime \prime} \mathrm{S}$ & $069^{\circ} 31^{\prime} 24^{\prime \prime} \mathrm{W}$ \\
\hline S. compressus & ICN 8173 & Boyacá, Serranía de las Quinchas & $05^{\circ} 49^{\prime} 29^{\prime \prime} \mathrm{N}$ & $074^{\circ} 19^{\prime} 30^{\prime \prime} \mathrm{W}$ \\
\hline S. compressus & ICN 8375 & Guainía, Puerto Inirida & $03^{\circ} 51^{\prime} 59^{\prime \prime} \mathrm{N}$ & $067^{\circ} 55^{\prime} 54^{\prime \prime} \mathrm{W}$ \\
\hline S. compressus & ICN 9022 & Putumayo, Mocoa & $01^{\circ} 05^{\prime} 58^{\prime \prime} \mathrm{N}$ & $076^{\circ} 34^{\prime} 06^{\prime \prime} \mathrm{W}$ \\
\hline S. compressus & ICN 10525 & Caquetá, Solano, Puerto Abeja & - & - \\
\hline S. compressus & ICN 10545 & Amazonas, Leticia & $04^{\circ} 01^{\prime} 24^{\prime \prime} \mathrm{S}$ & $070^{\circ} 06^{\prime} 58^{\prime \prime} \mathrm{W}$ \\
\hline S. compressus & ICN 12021 & Casanare, San Luis de Palenque & - & - \\
\hline S. compressus & ICN 12025 & & - & - \\
\hline S. compressus & ICN 14915 & Meta, Puerto López & $04^{\circ} 04^{\prime} 00^{\prime \prime} \mathrm{N}$ & $072^{\circ} 52^{\prime} 00^{\prime \prime} \mathrm{W}$ \\
\hline S. compressus & MHUAN-R 14733 & Antioquia, San Carlos & $06^{\circ} 10^{\prime} 26^{\prime \prime} \mathrm{N}$ & $074^{\circ} 45^{\prime} 05^{\prime \prime} \mathrm{W}$ \\
\hline S. compressus & MLS-722 & Boyacá, Macanal & $04^{\circ} 55^{\prime} 00^{\prime \prime} \mathrm{N}$ & $073^{\circ} 15^{\prime} 00^{\prime \prime} \mathrm{W}$ \\
\hline S. compressus & UTCH:COLZOOCH-H:0791 & Chocó, Nuquí & $05^{\circ} 50^{\prime} 36^{\prime \prime} \mathrm{N}$ & $077^{\circ} 16^{\prime} 38^{\prime \prime} \mathrm{W}$ \\
\hline
\end{tabular}

\section{Methods}

Our update of the distribution of Siphlophis is based on the revision of catalogued specimens in 5 zoological museums in Colombia (Reptile collection of Universidad de los Andes, Bogotá; reptile collection of Instituto de Ciencias Naturales, Universidad Nacional de Colombia, Bogotá; Instituto Alexander Von Humboldt, Claustro San Agustin, Villa de Leyva; reptile collection of Museo Herpetológico Universidad de Antioquia, Medellín; and Museo la Salle, Universidad de la Salle, Bogotá) (Table 1). The identification of specimens in the Reptile collection of Escuela de Biología de la Universidad Industrial de Santander (Bucaramanga, Santander) and the Colección Científica de Referencia Zoológica del Chocó, Universidad Tecnológica del Chocó (Quibdo, Choco), were confirmed by John Douglas Lynch. The distribution maps were made in the Geographical Information System program ArcGIS Online (https://www.arcgis.com/home/ index.html), using the coordinates obtained from the analysis of specimens in zoological museums.

The taxonomic identification and morphological interspecific comparisons (Tables 2, 3) were made based on literature data (Roze 1966, Peters and Orejas-Miranda 

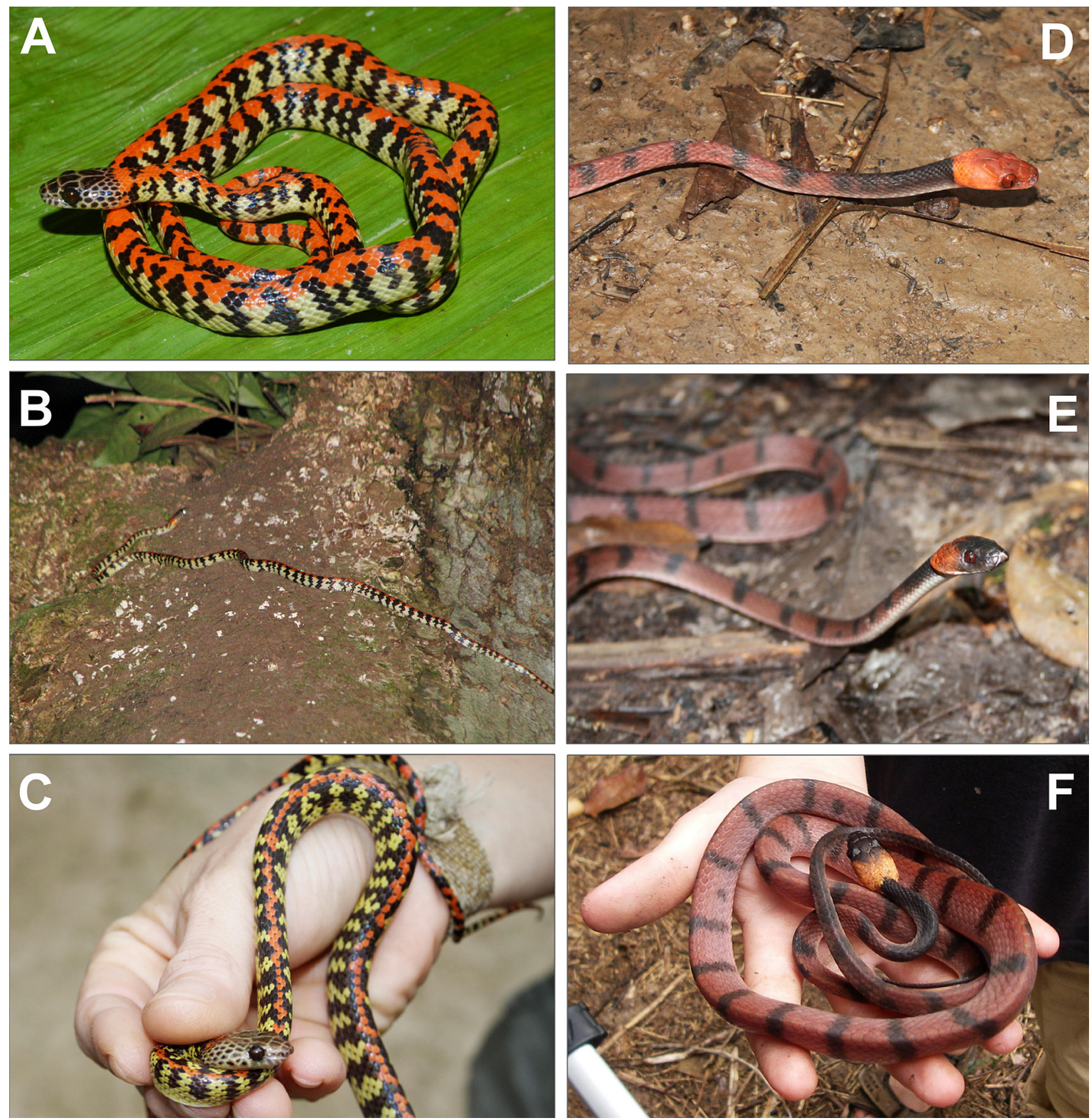

Figure 1. Individuals of Siphlophis cervinus (A-C) and Siphophis compressus (D-F) from Colombia. A, B. S. cervinus from Hacienda San Batolo, Municipality of Yondó, Antioquia, Middle Magdalena river region. C. S. cervinus from Reserva Tanimboca, Leticia, Amazonas. D. S. compressus from Santa Sofia, Leticia, Amazonas. E, F. S. compressus from Reserva Tanimboca, Leticia, Amazonas. Photographs by Fernando Vargas Salinas (A), Juan David Sánchez (B), Andrés Aponte Gutiérrez (C, D), and Goran Mihaijlovik (E, F).

1970, Dixon and Soini 1977, Chippaux 1986, Pérez-Santos and Moreno 1988, Barrio et al. 1998), and the advice of John Douglas Lynch. We compared scale accounts of some specimens from different regions in South America, to verify some geographic variation among Siphlohpis species from Colombia. For S. cervinus we collected scale data of specimens from Amazonas: ICN 096, ICN 8153, IAVH-R 3858; Chocó: IAVH-R 1967; and Middle Magdalena Valley: ICN 11156, ANDES-R 0306. For $S$. compresuss we collected scale data of specimens from Amazonas: ICN 9022, ICN 10545; Chocó: ICN 1524; Middle Magdalena Valley: IAVH-R 0143; and Orinoquia: ICN 12021, IAVH-R 3395, IAVH-R 5767.

\section{Results}

The genus Siphlophis is diagnosed by the presence of sulcated maxillary teeth (the third to fifth teeth are the largest), grooved rear fangs, smooth scales, vertebral scales longer than paravertebral scales, subcaudals divided, anal scale entire, and more than one anterior temporal scale (Peters and Orejas-Miranda 1970, Barrio et al. 1998).

Siphlophis cervinus (Laurenti, 1768): Figure 1A-C Siphlophis cervinus Laurenti 1768: 88; Peters and Orejas-Miranda 1970: 281; Pérez-Santos y Moreno 1988: 311; Barrio et al. 1998: 49-53. 



Figure 2. Geographic distribution of two Siphlophis species in Colombia. A. Siphlophis compressus occurrence data (red circles). B. Siphlophis cervinus occurrence data (blue triangles). See Table 1 for specific data associated to specimens in zoological museums in Colombia.

Lycognathus scolopax Dumeríl et al. 1854: 919.

Coronella cervina Laurenti 1768: 88

\section{Material examined. Table 1, Figure 2A}

Identification. Siphlophis cervinus is recognized by having a body pattern coloration with irregular light and dark markings (between 55 and 103 vertical black and white bats); third upper labial scale entering the orbit; venter with distinct black checks; vertebral region exhibiting red irregular coloration; third to fifth anterior mandibular teeth enlarged and contrasting with other mandibular teeth (Peters and Orejas-Miranda 1970).

Siphlophis compressus (Daudin, 1803): Figures 1D-F Siphlophis compressus Zaher and Prudente 1999: 700.

Coluber compressus Daudin 1803: 247.

Tripanurgos compressus Peters and Orejas-Miranda 1970: 311.

\section{Material examined. Table 1, Figure 2B}

Identification. Siphlophis compressus is differentiated from $S$. cervinus because the scales on the vertebral row are distinctly larger than the paravertebral row scales (Peters and Orejas-Miranda 1970), and the color pattern, that presents a dorsum red and black banded (strongly narrow) but the nape band is very wide, and the head is dark reddish-brown to black in some individuals (Dixon and Soini 1977) (Fig. 1A-F).

The analysis of 13 specimens (Table 1) suggests that $S$. cervinus in Colombia lives in lowland and piedmont for- est cover in the Amazon Basin, the Middle Magdalena Valley and the Choco Basin (Fig. 2B). In addition, based on data this species apparently is more often found in high strata of well-preserved forest. However, is possible to find individuals in forest remnants almost at ground level (ANDES-R 0306, see Table 1). By comparing scale counts among specimens from 3 regions in Colombia (Amazonas, Chocó and Middle Magdalena Valley), we observed that scale counts do not vary much, except for temporals (Table 2).

Based on 28 specimens, the distribution of S. compressus in Colombia includes the lowlands and piedmont of the Amazonas, Chocó, Magdalena Medio and Orinoquia regions. However, the specimen MLS 722 indicates that the species may be found in altitudes higher than $1000 \mathrm{~m}$ (Fig. 2A). Based on field and museum data, $S$. compressus is found both in preserved and disturbed forests, palm groves (such as Morichales) and mixed palm groves, generally with the presence of water bodies. The available information for this species does not suggest a preference for a specific plant stratum, individuals can be found at ground level or on the canopy. Considering that $S$. compressus has a wider distribution than S. cervinus, and based on the scale counts of specimens from 4 different regions (Amazonas, Chocó, Magdalena Medio and Orinoquia), we conclude that $S$. compressus exhibits low variability in scale counts (Table 3 ). 
Table 2. Scales counts in specimens of Siphlophis cervinus, Data were obtained in museums and literature. Numbers in parenthesis indicates the supralabial scales entering with the orbit; "with reduction" means that the specimen presents a reduction of dorsal scales to caudal region. A long dash (-) means that was not possible take a count of these scales because the condition of the specimen.

\begin{tabular}{|c|c|c|c|c|c|c|c|c|c|}
\hline \multirow[b]{2}{*}{ Scales } & \multirow[b]{2}{*}{$\begin{array}{l}\text { ICN } \\
096\end{array}$} & \multirow[b]{2}{*}{$\begin{array}{l}\text { ICN } \\
8153\end{array}$} & \multirow[b]{2}{*}{$\begin{array}{c}\text { ICN } \\
11156\end{array}$} & \multirow[b]{2}{*}{$\begin{array}{l}\text { ANDES-R } \\
0306\end{array}$} & \multirow[b]{2}{*}{$\begin{array}{c}\text { IAVH-R } \\
\mathbf{3 8 5 8}\end{array}$} & \multirow[b]{2}{*}{$\begin{array}{c}\text { IAVH-R } \\
1967\end{array}$} & \multirow{2}{*}{$\begin{array}{c}\text { Colombia } \\
\text { Pérez-Santos } \\
\text { \& Moreno } \\
1988\end{array}$} & \multirow{2}{*}{$\begin{array}{c}\text { Venezuela } \\
\text { Barrio et al. } \\
1998\end{array}$} & \multirow{2}{*}{$\begin{array}{c}\text { Fr. Guiana } \\
\begin{array}{c}\text { Chippaux } \\
1986\end{array}\end{array}$} \\
\hline & & & & & & & & & \\
\hline Rostral & 1 & 1 & 1 & 1 & 1 & 1 & 1 & 1 & 1 \\
\hline Internasal & 2 & 2 & 2 & 2 & 2 & 2 & 2 & 2 & 2 \\
\hline Prefrontal & 2 & 2 & 2 & 2 & 2 & 2 & 2 & 2 & 2 \\
\hline Frontal & 1 & 1 & 1 & 1 & 1 & 1 & 1 & 1 & 1 \\
\hline Parietal & 2 & 2 & 2 & 2 & 2 & 2 & 2 & 2 & 2 \\
\hline Supraocular & 1 & 1 & 1 & 1 & 1 & 1 & 2 & 1 & 1 \\
\hline Nasal & 1 & 1 & 1 & 1 & 1 & 1 & 2 & 2 & 1 \\
\hline Loreal & 1 & 1 & 1 & 1 & 1 & 1 & 1 & 1 & 1 \\
\hline Preocular & 1 & 1 & 1 & 1 & 1 & 1 & 1 & 1 & 1 \\
\hline Postocular & 2 & 2 & 2 & 2 & 2 & 2 & 3 & 2 or 3 & 2 \\
\hline Temporal & $3+4$ & $2+3$ & $\begin{array}{c}1+3+3 \& \\
2+2\end{array}$ & $2+2+3$ & $\begin{array}{c}1+3+4 \& \\
1+3+2\end{array}$ & $2+3$ & $1+2$ & $2+3$ & $\begin{array}{c}2+3+4 \text { or } \\
3+3+4\end{array}$ \\
\hline Supralabial & 8 & 8 & 8 & 8 & 9 & 8 & 9 & 8 & 8 \\
\hline $\begin{array}{l}\text { (in contact with } \\
\text { orbit) }\end{array}$ & $4-5$ & $4-5$ & $4-5$ & $4-5$ & $4-5$ & $4-5$ & $4-5$ & $4-5$ & $4-5$ or $3-4-5$ \\
\hline Infralabial & 9 & 9 & 9 & 9 & 10 & 9 & 8 & 8 & 9 or 10 \\
\hline $\begin{array}{l}\text { Dorsals } \\
{ }^{*} \text { with reduction }\end{array}$ & $19^{*}$ & $19^{*}$ & $19 *$ & $19 *$ & 19 * & $19 *$ & 19 & $19 *$ & $19 *$ \\
\hline Ventrals & _- & 255 & - & 241 & 240 & 258 & 229 & $240-252$ & $242-252$ \\
\hline Subcaudals & - & 116 & - & 106 & 106 & 103 & 105 & $108-124$ & $111-124$ \\
\hline
\end{tabular}

Table 3. Scales counts in specimens of Siphlophis compressus. Data were obtained in museums and literature. Numbers in parenthesis indicates the supralabial scales entering with the orbit; "with reduction" means that the specimen present a reduction of dorsal scales to caudal region."- " means that was not possible take a count of these scales because the condition of the snake.

\begin{tabular}{|c|c|c|c|c|c|c|c|c|c|c|}
\hline & & & & & & & & Colombia & Venezuela & Fr. Guiana \\
\hline Scales & $\begin{array}{c}\text { ICN } \\
9022 \\
\end{array}$ & $\begin{array}{c}\text { ICN } \\
10545\end{array}$ & $\begin{array}{c}\text { ICN } \\
1524 \\
\end{array}$ & $\begin{array}{c}\text { ICN } \\
12021 \\
\end{array}$ & $\begin{array}{c}\text { IAVH-R } \\
5767 \\
\end{array}$ & $\begin{array}{c}\text { IAVH-R } \\
0143 \\
\end{array}$ & $\begin{array}{c}\text { IAVH-R } \\
3395 \\
\end{array}$ & $\begin{array}{c}\text { Pérez-Santos } \\
\text { \& Moreno } \\
1988 \\
\end{array}$ & $\begin{array}{l}\text { Roze } \\
1966 \\
\end{array}$ & $\begin{array}{c}\text { Chippaux } \\
1986 \\
\end{array}$ \\
\hline Rostral & 1 & 1 & 1 & 1 & 1 & 1 & 1 & 1 & 1 & 1 \\
\hline Internasal & 2 & 2 & 2 & 2 & 2 & 2 & 2 & 2 & 2 & 2 \\
\hline Prefrontal & 2 & 2 & 2 & 2 & 2 & 2 & 2 & 2 & 2 & 2 \\
\hline Frontal & 1 & 1 & 1 & 1 & 1 & 1 & 1 & 1 & 1 & 1 \\
\hline Parietal & 2 & 2 & 2 & 2 & 2 & 2 & 2 & 2 & 2 & 2 \\
\hline Supraocular & 1 & 1 & 1 & 1 & 1 & 1 & 1 & 2 & 1 & 1 \\
\hline Nasal & 2 & 2 & 1 & 1 & 2 & 1 & 1 & 2 & 2 & 2 \\
\hline Loreal & 1 & 1 & 1 & 1 & 1 & 1 & 1 & 1 & 1 & 1 \\
\hline Preocular & 1 & 1 & 1 & 1 & 1 & 1 & 1 & 1 & 1 & 1 \\
\hline Postocular & 2 & 2 & 2 & 2 & 2 & 2 & 2 & 2 & 2 & 2 \\
\hline Temporal & $2+3 \& 2+4$ & $2+3$ & $2+3$ & $2+3$ & $2+3$ & $2+3$ & $2+3$ & $2+3$ & $\begin{array}{l}2+3 \text { or } \\
2+2+3\end{array}$ & $\begin{array}{c}2+3,4+3 \\
\text { or } 4+4\end{array}$ \\
\hline Supralabial & 8 & 8 & 8 & 8 & 8 & 8 & 8 & 8 & 8 & 8 \\
\hline $\begin{array}{l}\text { (in contact with } \\
\text { orbit) }\end{array}$ & $4-5$ & $4-5$ & $4-5$ & $4-5$ & $4-5$ & $4-5$ & $4-5$ & $4-5$ & $4-5$ & $4-5$ \\
\hline Infralabial & 9 & 9 & 9 & 9 & 9 & 9 & 9 & 9 & 9 & 9 \\
\hline $\begin{array}{l}\text { Dorsals } \\
{ }^{*} \text { with reduction }\end{array}$ & 19 & 19 & 19 & 19 & 19 & 19 & 19 & 19 & 19 & 19 \\
\hline Ventrals & 254 & 249 & - & 242 & 252 & - & 229 & $228-258$ & $228-258$ & $232-254$ \\
\hline Subcaudals & 104 & 121 & - & 112 & 122 & - & 98 & $110-125$ & $110-125$ & $110-121$ \\
\hline
\end{tabular}

\section{Discussion}

When our records of $S$. cervinus are compared with those collected by Pérez-Santos and Moreno (1988) and Sánchez et al. (1994), our study extends the species distribution in Colombia to the departments of Amazonas, Antioquia, Boyacá, Caquetá, Santander, and Vaupés. The same comparison for $S$. compressus extends the species distribution to the departments of Antioquia, Arauca, Caquetá, Guainía, Risaralda, Santander, Vaupés and Vichada. Sánchez et al. (1994) did not mention $S$. compressus from the departments in the Magdalena valley region (i.e. Boyacá, Risaralda, Santander). Summing up, S. cervinus and S. compressus exhibit wide distributions and predominate in the lowlands and piedmont of Colombia. 
For $S$. cervinus we observed that the distribution in Colombia is considered broad, but according to the records obtained from the biological collections, this species does not inhabit the Orinoco basin and Caribbean region. Although this species has been recorded in the Orionoco basin in Venezuela, near Colombia (Barrio et al. 1998), and in the northernmost region of the Orinoco (Flores-Padrón et al. 2016), in both papers the authors stated that individuals were only found in preserved humid forests, in which vegetation cover is similar to Guyaneses and Amazonian forests. Therefore, we suppose that $S$. cervinus could be found in similar vegetal coverages on the Colombian Orinoco basin, such as those in the department of Vichada (Rangel-Ch 2014). In addition, Flores-Padrón et al. (2016) found S. cervinus at nearly $1000 \mathrm{~m}$ above sea level (a.s.1.), which suggests that the species distribution in Colombia can be vertically extended by further data.

$S$. compressus seems to be widely distributed in Colombia, but it does not inhabit the Caribbean region. This species has been found in lowlands, piedmont and highlands (above $1000 \mathrm{~m}$ a.s.1.), which is consistent with the information obtained by Barrio-Amorós et al. (2010).

We observed no geographic pattern in the scale counts for both $S$. cervinus and $S$. compressus. When our data were compared with the literature data from Colombia, Venezuela, and French Guiana (Roze 1966, Chippaux 1986, Pérez-Santos and Moreno 1988, Barrio et al. 1998), we did not observe significant variation in scale counts. Nevertheless, in order to test morphological variation and evolutionary divergence among Siphlophis populations, further morphological (e.g. hemipenis, coloration patterns, skeletal, and muscular structures), and ecological data (e.g. diet and habitat preferences) are necessary.

\section{Acknowledgements}

Authors thank John Douglas Lynch for the data and tips given during the elaboration of this manuscript; Marta Calderón (Instituto de Ciencia Naturales, Universidad Nacional de Colombia), and Claudia Medina and Carlos Montaña (Instituto Alexander Von Humboldt, Claustro San Agustín, Villa de Leyva, Colombia) for allowing the revision of specimens in zoological museums. We also thank to Juan Pablo Hurtado and Teddy Angarita for the help provided in the revision of specimens. Finally, thanks to Carlos Gantiva for the elaboration of distribution maps.

\section{Authors' Contributions}

AAP revised the museum specimens, and AAP and FVS wrote the text.

\section{References}

Almendariz A (1991) Anfibios y Reptiles del Ecuador. Revista Politécnica 16 (3): 89-162.

Barreto T, Siqueira GS, Da Costa AL, Marques OV (2011) New records and geographical distribution of the Tropical Banded Treesnake Siphlophis compressus (Dipsadidae) in Brazil. Herpetology Notes 4: 341-346.

Barrio CL, Navarrete LF, Fuentes O, Mattei R (1998) Siphlophis cervinus (Serpentes, Colubridae) en Venezuela. Acta Biológica Venezuelica 18 (1): 49-53.

Barrio-Amorós CL, Chacón-Ortiz A, Diasparra JP, Orellana AM, Bautista J, Molina C (2010) Distribution of Siphlophis compressus (Daudin, 1803) in Venezuela with a remarkable geographic extension. Herpetozoa 23 (1/2): 100-103.

Cadle JE (1992) On Colombian Snakes: Ofidios de Colombia by Carlos Pérez-Santos; Ana G. Moreno. Herpetologica 48 (1): 134-143.

Chippaux JP (1986) Les serpents de la Guyane Francaise. Collection Faune Tropicale 27: 1-167.

Claessen H (2005) De slangen van de Guyana's. Deel VIII. Lacerta 63 (4): $136-151$.

Daudin FM (1803) Histoire Naturelle Generale et Particuliere des Reptiles. Vol. 6. F. Dufart, Paris, 320 pp.

Dixon JR, Soini P (1977) The reptiles of the upper Amazon basin, Iquitos region, Peru. II. Crocodilians, turtles and snakes. Contributions in Biology and Geology 12: 1-91.

Duellman WE, Salas AW (1991) Annotated checklist of the amphibians and reptiles of Cuzco Amazonico, Peru. Occasional papers of the Museum of Natural History, the University of Kansas 143: 1-13.

Duméril AMC, Bibrón G, Duméril AHA (1854) Erpétologie générale ou histoire naturelle complète des reptiles. Tome septième. Deuxième partie, comprenant l'histoire des serpents venimeux. Librairie Encyclopédique de Roret, Paris, 1536 pp.

Espinoza NC, Icochea J (1995). Lista taxonómica preliminar de los reptiles vivientes del Perú. Publicaciones del Museo de Historia Natural, Universidad Nacional Mayor de San Marcos, Lima, 27 pp.

Flores-Padrón D, De Freitas M, Camargo E (2016) Primer reporte al norte del río Orinoco para Siphlophis cervinus (Laurenti, 1768) (Serpentes: Dipsadidae: Xenodontinae) en la península de Paria, Estado Sucre, Venezuela. Saber 28 (1): 171-176.

Frota JG, Pedroso A, Menezes-Chalkidis H, Guimaraes A (2005) As serpentes região do Baixo da Amazon river, Estado Oeste do Pará, Brasil (Squamata). Biociencias 13 (2): 211-220.

Gasc JP, Rodrigues MT (1980) Liste preliminaire des serpents de la Guyane française. Bulletin de musée d'Histoire naturelle 2 (4): 559-598.

Grazziotin FG, Zaher H, Murphy RW, Scrocchi G, Benavides MA, Zhang YP, Bonatto SL (2012) Molecular phylogeny of the New World Dipsadidae (Serpentes: Colubroidea): a reappraisal. Cladistics 28 (5): 437-459. https://doi.org/10.1111/j.1096-0031.2012.00393.x

Laurenti JN (1768) Specimen medicum, exhibens synopsis reptilium emendatam cum experimentum circa venena et antidota reptilium austracorum, quod authoritate et consensu. Joan Thomae, Vienna, 217 pp.

Pérez-Santos C (1999) Serpientes de Panamá. Publicaciones del Comité Español del Programa MaB y de la Red IberoMaB de la Unesco, Madrid, 312 pp.

Pérez-Santos C, Moreno AG (1988) Ofidios de Colombia. Monografie VI. Museo Regionale di Scienze Naturali, Torino, 517 pp.

Peters JA, Orejas-Miranda B (1970) Catalogue of the Neotropical Squamata; part 1. Snakes. United States National Museum, Bulletin 297: 1-347.

Rangel-C JO (2014) La región de la Orinoquía de Colombia. Colombia Diversidad Biótica XIV. Universidad Nacional de Colombia, Insti- 
tuto de Ciencias Naturales, Bogotá, 895 pp.

Sánchez-C H, Castaño-M O, Cárdenas-A G (1994) Diversidad de los reptiles en Colombia. In: Rangel-C JO, Castaño O, Styles G, Ruiz P, Lowy P, Sánchez H, Aguilar M, Garzón A, Cuartas D (Eds) Estudio de la biodiversidad en Colombia. Documento interno del Proyecto Estudio de la Biodiversidad en Colombia. Convenio Inderena-Universidad Nacional de Colombia, Bogotá, Colombia, $277-326$
Solórzano A (2004) Serpientes de Costa Rica: distribución, taxonomía e historia natural. Instituto Nacional de Biodiversidad, San José, Costa Rica, 792 pp.

Uetz P, Freed P, Hosek J (2016) The Reptile Database. Versión 2016. http://www.reptile-database.org/. Accessed on: 2017-9-12.

Zaher H, Prudente LC (1999) Intraspecific variation of the hemipenis in Siphlophis and Tripanurgos. Journal of Herpetology 33 (4): 698-702. 